\title{
The Kardashians : A Parasocial Phenomenon
}

\section{Joshua Eldi Setio}

Mahasiswa Jurusan Hubungan Internasional, Fakultas IImu Sosial dan IImu Politik, Universitas Katolik Parahyangan

\begin{abstract}
Abstrak
Tayangan Realitas Keeping Up With The Kardashians membawa keuntungan besar pada keluarga Kardashian yang sekarang menikmati ketenaran dan kekayaan dari kegiatan tersebut tetapi apakah yang membuat keluarga Kardashian menjadi sangat terkenal? Mereka tidak menampilkan tarian atau menyanyi, mereka hanya tampil di acara realitas yang menampilkan kegiatan sehari-hari mereka dan mereka dibayar jutaan dollar untuk melakukannya, mereka juga membombardir para penggemar mereka dengan gambar dan snap tentang keseharian mereka. Paper ini dibuat untuk menjelaskan sebuah fenomena media internasional yang dimanfaatkan oleh keluarga Kardashian: penggunaan Soft Propaganda dalam berbagai sarana untuk memasarkan diri mereka kepada para pemirsa, Soft Propaganda sendiri mengacu kepada kegiatan propaganda yang memiliki tujuan untuk tujuan low politics yang tidak bersifat konfliktual seperti propaganda masa perang yang digunakan untuk menghadirkan dikotomi "kita-mereka". Fenomena ini bukanlah sesuatu yang baru karena kita semua tahu bahwa setiap propaganda menggunakan interaksi parasosial untuk mempengaruhi para penerima pesan, tetapi dengan pengembangan teknologi media komunikasi membuat dampaknya jauh lebih besar di masa digital. Sejak lama sudah terbukti bahwa Komunikan dapat merasakan keintiman dengan komunikator tanpa harus bertemu secara langsung, namun peristiwa ini juga dapat menimbulkan masalah psikologis seperti radikalisasi dan pemujaan berlebihan terhadap idola. Memahami isu ini dapat membantu kita mengerti tentang penggunaan propaganda dalam lingkup sehari - hari baik dalam konteks bisnis maupun politik. Paper ini juga bertujuan untuk mengembalikan ketertarikan para peneliti kontemporer terhadap studi kebudayaan modern.
\end{abstract}

Kata Kunci : Keintiman Para-Sosial, Kardashian, Propaganda, Media.

RQ : How did the Kardashians use Soft Propaganda to their own advantage?

\section{THEORITICAL FRAMEWORK}

The analysis are based on the theory of Para-social intimacy, in explaining it let's take it like this : in a communication through mass media there will be two kind of factions (we may see this as our variables), the first is the content maker (television or radio companies and even the owner of a popular social media

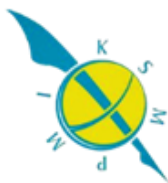


account) and the audiences (those who are receiving the messages). The ParaSocial Intimacy stated that it is possible that the audience has a sense of intimacy in some sense of way which could be decribed as "a sense of closeness or feeling of being related from the audience of a mass media to certain personalities that act as their communicator" this phase is achieved after the communican / the receiver is receiving a huge number of messages infused on their minds, the word huge number means that the information from the communicator has been received in a regular or habitual level by the receiver, this could happened from the social media (with the followers - based sharing system). The Para-Social Intimacy is visible in our everyday life and in various mass media that could be accessed by a large number of people, the example of Para-Social intimacy in traditional (non-digital) communication media is the pictures in the printed media, after the attack on Pearl Harbor on 1941, the U.S newspapers printed photos of the wounded army member and civilian as their cover story, this sparks anger and sadness in their readers, they felt empathy and sympathy for the people in the photos that they never even meet their whole life, in a more modern context, by watching a motion picture or a television program that has a tragic or sad story on how the protagonist are being beaten down in life, this is set to make the viewers relate to the protagonist and emphatize or sympathize with the protagonist's cause. The influence of the parasocial intimacy is visible in the later stage of communication which saw how the informations the audiences gathered are being influential in their decision making in everyday life such as fashion, choices of friends, style of communication and more. Another factor that supports the para-social intimacy is the Soft Propaganda, the term soft propaganda is to refer to a propaganda activity that most people don't even recognize because the message of the propaganda that are aimed to the audiences are not as explicit as their Hard Propaganda counterpart which are more subtle in conveying their messages (e.g. the wartime propaganda which creates a dychotomy between us, our allies and our enemies by demonizing the opposing side), also the characteristics of Soft Propaganda that are being used here is that it was never meant

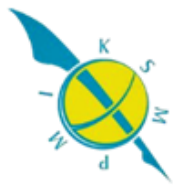


to create a dychotomy of us and them like the wartime propaganda did to the audience, instead it focus on slipping messages trough their contents to influence and gain attention from the audience. Normatively, people would need to trust the communicator before proceed to take his/her advices, and to trust someone we would need to gain some degree of intimacy and closeness, the Para-Social intimacy creates a sense of sympathy for the communicator in the audience's mind, and so make the audience feel a kind of closeness with the communicator, this closeness can be built more into the point where they trust the words and advices or even directions from the communicators and that is what Kardashians do best, one question remain, how ?

\section{PROBLEMATICS}

The Problem with Para-Social Intimacy combined with propaganda style of information sharing such as bombardment of images, snaps and other contents that only promote the positive sides of the communicator or their cause is that the public that act as their audience does not informed well and so their decision making is highly influenced by the limited information their communicators gave them this could lead to some unwanted actions but arguably the most apparent example is from the Sasaeng fans ${ }^{1}$ in the Hallyu / Korean Wave, these fans were receiver of the messages from various medias such as Youtube, television programs, music, tweets and print medias that contained the life of their idols, their views on things, and they were bombarded by this for a long time, and makes them "in love" or having a sense of intimacy and relatability with their idols, best case scenario it will only increase spending for luxury goods for pleasure such as CDs , posters, ticket to concerts and so on but the worst case scenario is dangerous, numerous cases tell us about fans that cut their veins to get the attention from their idols, some cases also report that suicide among fans happened when a popular group is being left by one of it's members, and

\footnotetext{
1 "Sasaeng Fans Attacks EXO in the Air", KpopMap.com, accessed 16 November 2016, http://www.kpopmap.com/sasaeng-fans-attack-exo-on-the-air/
} 
ISSN 0216-5031

$\mathrm{H}$ a I a m a n | 84

those kind of cases. But we can never always point to the idols, celebrities or their agencies for this kind of problems, they only wanted to make an intimacy between the celebrity and the fans, and so the aftermath , the action or decision that are being taken by the audiences or the communicans are sometimes out of the communicators control, but on the other hand still, the after effects of the para-social intimacy are being caused by the propaganda that being used by the communicators, so in this case if we speaking normatively, the actions of the communicans are being influenced hardly by their communicators's messages.

\section{DISCUSSION}

\section{The Kardashians}

The Kardashians are family of five consisted of sisters Kendall, Kim , and Kylie with their respective parents Bruce Jenner and Kris Kardashian. The first member to hit the stardom is te daughter Kim Kardashian trough the leak of her sex tape. Kim took the family to the supertardom through the reality Tv Show Keeping Up With the Kardashians that first aired in $2007^{2}$. The show itself showcased the everyday life of the Kardashians following their life and relationships with each other and their respective spouses (Kanye West, Blac Chyna), the reports constantly mentioned that the show has created a constantly high rating ${ }^{3}$ and keep being renewed for another season of broadcast ${ }^{4}$. The success of the show spawned a number of spinoff that focused on individual life of the members of the Kardashian family such as Khloe and Kourtney (Khloe and Kourtney takes on Miami), Bruce / Caitlyn Jenner (I Am Caitlyn) and Kourtney and Kim Take New York that has been quite sucessful with the similiar formula of the Keeping Up With The Kardashians. The members of the

\footnotetext{
2 "Keeping Up With The Kardashians", TvGuide.com , accessed 16 November 2016, http://www.tvguide.com/tvshows/keeping-up-with-the-kardashians/290833/

3 "Keeping Up With The Kardashians ratings", tvbythenumbers.com, accessed 16 November 2016, http://tvbythenumbers.zap2it.com/tag/keeping-up-with-the-kardashians-ratings/

4 "Keeping Up With The Kardashians spin off : the "DASH dolls" coming up to our screen, accessed 16 November 2016, http://www.sugarscape.com/film-

tv/news/a1076648/kardashians-spin-off-dash-dolls/
} 
family also capitalize on their success by posing for the tabloid cover, bombarding their followers with wide variety of posts in social medias such as Instagram, Snapchat and Twitter ${ }^{5}$, regularly portraying their glamour lifestyle as Hollywood socialites while subvertly promoting some items from their sponsors.

The Family Kardashians are not only famous of sensations, they are also bussinessmen and women with successful ventures everywhere such as Kylie Jenner that started the brand Kylie Lip Kit which is popular in the late 2015s , Khloe and Kourtney also run the clothing line Dash particularly based in Miami. But income doesn't only come from the Kardashians, with marriage to Kanye West, The Kardashians also gain access to the hip - hop artist's coffers, West also already popular as a musician and has a side - income from the bussinesses he ran since before his marriage with Kim Kardashian. These other family members of the Kardashian clans also very active in the media.

\section{The Propaganda}

The Aims that is being pursued by The Kardashians are the Psychological Action and Public and Human Relation. ${ }^{6}$ They try to influence the lifestyle and decision making preferences of the masses (especially their audiences), their influence later will direct their audiences to support the Kardashian's sponsors by buying the products the Kardashians endorse, for example the use of Social Media (e.g Instagram) by Kim Kardashian which boost make up sales by $14.3 \%$.

The Kardashians are famous in huge part thanks to the success of the soft propaganda they enacted and conducted everyday in every platform they could

\footnotetext{
5 "The Kardashians Social Media Influence", Forbes.com, accessed 15 November 2016, http://www.forbes.com/forbes/welcome/?toURL=http://www.forbes.com/sites/seamuskir st/2015/12/17/the-kardashians-social-mediainfluence/\&refURL=https://www.google.com/\&referrer=https://www.google.com/ 6

7 “Kim Kardashian's selfie increase Make Up sales”, BBCnews.com, accessed 14 November 2016, http://www.bbc.com/news/business-34324236
}

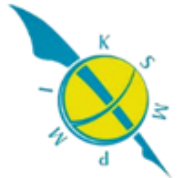


utilize. And this brings us to one of the external characteristics of a propaganda : propaganda is not creating something out of nothing and this is what catapults them to fame : Keeping Up With The Kardashians are set to be a "real" experience on the Kardashians, by portraying the supposedly "real life" of Kardashians they gain attention by the people who admired and astonished by their "real" glamorous and drama-filled life even if there is allegedly scripted parts of the show. Another characteristics is also the constant "bombardment" of their snaps, pictures and videos all over print covers, TV and social media to constantly adjust the focus of the people and audiences to only pay attention for them, specifically the interesting and positive part of the Kardashians that sells and attract viewership, gossip rags, this creates more attention for the Kardashians, which then bring more money for them because the producers believe that they could promote their shows and products to influence the audience to watch or buy them. But a propaganda could not be successful without an organization planning and executing the propaganda, and here's we can marvelously see the Kardashians as a bussiness unit other than a family, other than their affiliation to studios and production houses, the Kardashians themselves organize their members of the family to support each other through variety of media, one of the most apparent of this is the creation of spin offs from Keeping up With The Kardashians this is not only to capitalize on the fame of Kim Kardashian but also to keep balance to the hype the Kardashians are very dependant upon, to prevent boredom and also to produce a lot more of interesting dramas ${ }^{8}$, it is a strategy that multiply the viewership through a show with similiar formula. Another external characteristics of their propaganda is that they are not pointing to one particular audience as they used social medias, which in basics are a tool to spread information to as many people as possible altough they do not aim to get the "following" and acceptance from all the people around the world and presumably already know the demographics that has the most affection on them, urban-cultured youth.

\footnotetext{
8 "Tv Gets Social : Evaluating Social Media data to explain vriability of Nielsen Ratings", Nina Stratt Lerner, published 18 December 2011, Accessed 17November 2016.
} 
ISSN 0216-5031

$\mathrm{H}$ a I a m a n $\mid \mathbf{8 7}$

And then we need to understand, how do they use this propaganda to favor their cause ?, to explain this we will need to take the concept of the Para-Social Intimacy in the analysis. The main concept of Parasocial intimacy is that people should feel close to the communicator without even need to interact with the communicator at all. This has been used by Kim and the Kardashians to promote not only their sponsors items but also themselves, they don't use the concept of Transfer or Reputable Mouthpiece (the concept of propaganda and advertisement in which the communicator use the famous personality to promote a product) and appear as if they are famous person telling you to buy something instead they present themselves as your everyday friend that seems to be close with you and recommends you some things she knows that will do good for you, this kind of closeness (according to the theory) will make the communican or the audience more easy to be persuaded because they sense familiarity with the communicators just like get an advice from a close friend. In the long run, the Kardashians silently spread the urban culture such as modern pop music, night life in clubs and parties, glamour life and "american dream" philosophy like individual freedom, sexual freedom, and so on, after their values and philosopy spread and be accepted by some parts of society, this will create a Bandwagoning situation, where the slowly growing cult of Kardashians followers became a dominant force in the society, and because they became a dominant group, more and more members try to join them because it's as if the dominant group creates a new trend of lifestyle in fashion, food, and others and so the ordinary people can have more friends easily, they try to imitate the style of the majority to be identified by the larger group as a part of them because the people has similiar characteristics physically or psychologicaly or both.

How do the Kardashian then make fortune from this? , first the Kardashians maintain their popularity trough various dramas in their own reality show ${ }^{9}$, Keeping Up With

\footnotetext{
9 “Keeping Up With The Kardashians salary revealed!", mirror.co.uk, Accessed 14 November 2016, http://www.mirror.co.uk/3am/celebrity-news/keeping-up-kardashianssalaries-revealed-5303897
} 
The Kardashians and then capitalize on it's success by spanning more and more spinoff for specific family members ${ }^{10}$, this strategy makes them gain more income of licensing their presence and also indirectly promoting their other endeavours such as the brand $D A S H^{11}$ created by sisters Khloe and Kim, and then the Kylie cosmetics collections. By this strategy of preserving their identity as pop culture icons that are relevant for their huge audiences in the international level, given the United States's media worldwide appeal the Kardashians has shown us that propaganda could also be used for bussiness endeavours.

But their influence doesn't stop in the domestic media market in United States where they are based, with the rise of new technology appliance in the media and it's related industry, the impact made by the Kardashians are now a global phenomenon,they may not be the one who start to use the social media as an effective marketing platform for themselves but they are the one who prolonged an era of effective use of mentioned platform globally. But as all the propaganda do, the communicans are only being informed by a one sided information which is the information that the Kardashians and their bussiness aquintances export to the global audience but we never really know who the Kardashians are, do they really behave like that? Is it true that the whole Kardashian family is that rich? Are they a group of "dumb" urban americans as they are in the screen or a group of genius minds that understand marketing best. Understanding this can help us understand another issue that is worth it's own analysis, the issue of Donald Trump's use of media such as his regular appearance in The Apprentice reality series. Using the same framework we can see how the public see Trump through his shows as a great intuitive, charismatic, strong authoritarian leader while actually he can be considered as a mediocre

\footnotetext{
10 "The Kardashians are getting more spin offs for Money", Cinemablend.com, Accessed 15 November 2016, http://www.cinemablend.com/television/Kardashians-Getting-AnotherSpinoff-Because-Money-71076.html 11 "The Kardashians made 65 million dollar lastyear and you didn't !", Eonline.com, accessed 17 November 2016, http://www.eonline.com/news/226698/the-kardashiansmade-65-million-last-year-and-you-didn-t
}

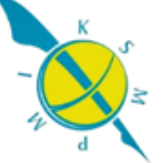


ISSN 0216-5031

bussiness magnate as his bussiness failures and bankruptcy (he went through chapter 11 bankruptcy, which is company bankruptcy not involve personal wealth).

\section{CLOSING REMARKS}

Trough the analysis, we may see that the Kardashian family and other people related to them or their affairs have great sense and intuition in using any means of social media available to their advantage. The constant activity of posting their life creates the parasocial intimacy with their audiences and made them more influential as the audience has a sense of closeness with the personalities they saw on daily basis as if the Kardashians are their friends. This research prove that parasocial intimacy can be utilized to gain financial or social advantage as proven by the activity of Kardashians family.This research paper also aim is to make people aware that the subject of research in the international communications especially in the study of propaganda and the media and also international bussiness is in fact still as relevant and as interesting as the discussions on high politics and it's issues. The study on the Parasocial intimacy itself still open wide on many subjects and other forms of the media such as Youtube, or other shows in television, films and others. Another case that is very interesting about this topic is the use of the reality $\mathrm{Tv}$ show, The Apprentice by then candidate (now the President Elect) Donald J. Trump as mentioned before. What we need to understand is that the study of the media is tangible in the information age we live in, we understand that we are influenced by the media and the information we consume, but we are often incapable to explain how we are being influenced by the media. we hope that this analytical paper will also raise interest in youth demography to do studies, we want them to notice that the topics of study is not always need to be "academic" like high politics and economics but also modern culture and it's use for humanities.

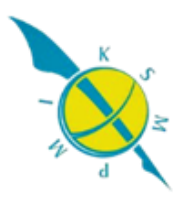




\section{Bibliography}

\section{Books}

Gorman,Lyn and David McLean, "Media And The Society into the $21^{\text {st }}$ Century", Oxford : Wiley-Blackwell, 2009.

Martin, Judith N., and Thomas K.Nakayama, "International Communications in Contexts", Arizona : McGraw-Hill, 2004.

Schramm, Wilbur et.al, "The Process and Effects of Mass Communications", Illinois : Library of Congress Press, 1954.

\section{Internet}

"Kim Kardashian's selfie increase Make Up sales", BBCnews.com, http://www.bbc.com/news/business-34324236.

"The Kardashians are getting more spin offs for Money", Cinemablend.com, , http://www.cinemablend.com/television/Kardashians-Getting-Another-Spinoff-BecauseMoney-71076.html.

"The Kardashians Social Media Influence", Forbes.com, http://www.forbes.com/forbes/welcome/?toURL=http://www.forbes.com/sites/seamuskir st/2015/12/17/the-kardashians-social-mediainfluence/\&refURL=https://www.google.com/\&referrer=https://www.google.com/. "The Kardashians made 65 million dollar lastyear and you didn't !", Eonline.com, http://www.eonline.com/news/226698/the-kardashians-made-65-million-last-year-andyou-didn-t.

"Sasaeng Fans Attacks EXO in the Air", KpopMap.com, http://www.kpopmap.com/sasaengfans-attack-exo-on-the-air/.

"Keeping Up With The Kardashians salary revealed!", mirror.co.uk, Lerner, Nina Stratt. "Tv Gets Social : Evaluating Social Media data to explain vriability of Nielsen Ratings", http://www.mirror.co.uk/3am/celebrity-news/keeping-up-kardashianssalaries-revealed-5303897

"Keeping Up With The Kardashians ratings", tvbythenumbers.com, http://tvbythenumbers.zap2it.com/tag/keeping-up-with-the-kardashians-ratings/

"Keeping Up With The Kardashians", available at TvGuide.com , http://www.tvguide.com/tvshows/keeping-up-with-the-kardashians/290833/.

"Keeping Up With The Kardashians spin off : the "DASH dolls" coming up to our screen, Available at Tvtrope.com, http://www.sugarscape.com/filmtv/news/a1076648/kardashians-spin-off-dash-dolls/.

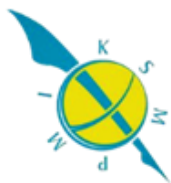

